International Journal of Instruction e-ISSN: 1308-1470 • www.e-iji.net

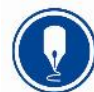

January $2022 \bullet$ Vol.15, No.1

p-ISSN: 1694-609X

pp. 153-166

Article submission code

20210113160211

Received: 13/01/2021

Revision: 08/06/2021
Accepted: 06/07/2021

OnlineFirst: 17/10/2021

\title{
Enhancement of Preservice Islamic Studies Teachers' Autonomous Learning Skills: Designing a Reverse Learning Project
}

\section{Kalthoum Alkandari}

Assoc. Prof., Curriculum \& Instruction, College of Education, Kuwait University, Kuwait,kkandari@hotmail.com

\section{Abdullah Al-Failakawei}

Asst. Prof., Curriculum \& Instruction, College of Education, Kuwait University, Kuwait, alfailkawei@yahoo.com

Early exposure to innovative teaching strategies is vital for preservice teachers' preparation for their subsequent teaching careers. This paper aimed to challenge preservice Islamic studies teachers at Kuwait University to enhance their autonomous learning by assigning them the task of designing a reverse learning project. The participants completed various phases to finalize the project. This exposition and exploration aimed to develop their sense of autonomy, selfregulation, responsibility, technology and design skills, and ability to incorporate the task into their specialized subject matter. The mechanism and practices that participants acquired through designing and executing the reverse learning project were examined qualitatively and quantitively to unveil the effect of this experience on their autonomous learning skills. The results revealed that exposing the participants to the reverse learning project promoted their sense of and beliefs toward self-regulation, responsibility, technology integration, and design for subsequent Islamic studies teaching. The positive learning experiences increased the participants' emotional, cognitive, and manageability levels; however, the findings demonstrate the need for further research on preservice teachers in other specializations and designing reverse learning projects.

Keywords: autonomous learning, reverse learning, preservice teachers, Islamic studies, Kuwait University

\section{INTRODUCTION}

Islamic education is often stigmatized as lacking innovative teaching strategies for the digitalized era. Traditional methods dominate Islamic education, and technology-based approaches are less applied and practiced (Zedan et al., 2015). Such stigma stemmed from the limited attempts to integrate technology with Islamic education teaching practices. The researchers' experience in teaching Islamic education and preparing prospective Islamic education teachers suggests that Islamic education teaching

Citation: Alkandari, K., \& Al-Failakawei, A. (2022). Enhancement of preservice Islamic studies teachers' autonomous learning skills: designing a reverse learning project. International Journal of Instruction, 15(1), 153-166. https://doi.org/10.29333/iji.2022.1519a 
strategies were modest about technology integration. Additionally, literature on the practice of integrating technology within Islamic education is limited. These reasons being the incentive for this study, innovative technological teaching strategies for prospective Islamic education teachers were developed to integrate technology into academic preparation, promote autonomous learning skills, and increase their ability to implement innovative teaching strategies. Further, to examine the stereotyping of traditional patterns for teaching Islamic education and whether Islamic education can and does cope with innovation, such as incorporating reverse learning (RL), a novel trend that has received considerable attention in educational research. This research highlights the outcomes of integrating such innovation and addressing transformations within Islamic education teaching practices.

This paper examined the experiences of preservice Islamic studies teachers at the Kuwait University College of Education in planning and designing their first RL project intended to promote autonomous learning (AL). The study examined the relationships among AL, design, technology, and innovation in teaching, linking these concepts to create a pedagogical paradigm for Islamic studies.

\section{The nature of Islamic education}

For decades, Islamic studies has been stigmatized as lacking creativity and relying highly on indoctrination. Islamic knowledge was viewed as a revealed or sacred message that should not be analyzed or taught through technology and perceived as lacking excitement or stimulus for learners (Alsadoon, 2012), and its teachers have been criticized for having low academic competency in teaching practices and technological skills integration (Al Juhami, 2008). However, Islamic studies can promote cognitive growth by providing learners with the necessary skills and competencies to promote authentic and reflective learning and critical thinking. The Quran, the primary focus of Islamic studies, devotes attention to the structural features of building cognitive knowledge. Rich examples from the Quran and Hadith and current events exemplify that Islamic studies curriculum promote constructive thoughts, discussions, and investigations among students (Alkandari \& Alsuwailan, 2019).

The Quran states that thinking is an exclusive characteristic of human beings, explaining that humans have been given the power and autonomy to think. This is illustrated by statements such as: "And do not pursue that of which you have no knowledge. Indeed, the hearing, the sight, and the heart - about all those [one] will be questioned" (17:36).

Encouragement for the search for knowledge in Islamic education is also mentioned in the Hadith, represented by this statement by the Prophet Mohammad (peace be upon him): "Seeking of knowledge is incumbent upon every Muslim" (Ibn-Majah). The Quran does not force or affirm Taqlid, the acceptance of any doctrine; rather, it encourages strong reasoning and emphasizes the search for truth and conclusions. Terms such as tafakkur (contemplating), tadabbur (pondering), tabassur (understanding), tawassum (reflecting), nazar (considering), I'tibar (taking a lesson), and tadhakkur (taking advice to heart) highlight the significance of thinking in Islam (Endut \& Abdullah, 2009). 
The Kuwait Ministry of Education sets standards for qualitative transitions in its educational innovation in learning policy. Recently, in partnership with the World Bank, the Ministry implemented a competency-based curriculum for all academic levels. One of these standards is incorporating technology into pedagogical practices in all academic areas, including Islamic studies (Kuwait Ministry of Education, 2013). The Kuwait University College of Education incorporates these objectives by allowing preservice Islamic studies teachers to learn these technical skills and promoting centric learning and AL skills. Subsequently, this study explored preservice Islamic studies teachers' learning experiences in designing an RL project and how it enhanced their AL skills.

\section{Reverse learning (RL) and autonomous learning (AL)}

Currently, higher educational development trends are focused on student-centered learning. AL provides more space and autonomy for learners as it allows students to understand their learning goals, develop study plans autonomously, apply learning strategies effectively, monitor learning strategies accurately, and evaluate the entire learning process actively ( $\mathrm{Li}$ et al., 2018, p. 522).

AL objectifies self-directed learning, promotes independent skills, and allows students to obtain significant education expertise. In the current globalized era, characterized by social media and technological innovations, learners must push beyond gaining knowledge to equip themselves with various self-directed, autonomous competencies and become more independent. This includes developing critical thinking skills, creativity, cooperation, and social skills such as communication while utilizing technology within their learning process (Duke, 2016). Incorporating these skills within the use of technology resulted in RL or the flipped classroom, where these learning approaches intertwine to produce accomplished, self-directed learners.

RL overlaps with several other terms: flipped learning, reverse instruction, backward classrooms, and inverted classrooms (Alvarez, 2012). RL in flipped classrooms is an innovative approach for promoting student-centric learning practices. Abeysekera and Dawson (2014) describe it as a range of pedagogical strategies that transform teaching beyond the traditional methods. RL allows students to enjoy a flexible learning environment that promotes active and perpetual learning outcomes (Kozikoğlu, 2019), active social learning, and discussion and communication. Students are required to complete class activities and use class time efficiently to enable social learning. This approach employs technological innovations to deliver content through video lectures, enabling active learning.

AL allows students to take charge of attaining their learning goals, including designing and planning their learning process. Students can effectively apply their practices and strategies, observe their learning process, and evaluate and reflect on this learning experience ( $\mathrm{Li}$ et al., 2018). RL incorporates technology into the learning process to enhance learner autonomy, focusing on personalizing time between students and their teachers (Bergman \& Sams, 2012).

RL helps students and teachers personalize their interactions and creates a platform to build strong, effective personal rapport (Nguyen et al., 2016). A significant advantage of 
applying RL is that it does not exclude interaction in multiple educational contexts but is rooted in creating a non-traditional sociocultural environment that is familiar for students. By employing RL, teachers highlight learning that accompanies watching online videos outside the class and working with materials. The teacher's role in RL is to empower students' AL, develop their critical thinking, encourage problem-solving, and promote group work. Thus, RL allows students to incorporate decision-making regarding content and technology (Li et al., 2018).

\section{Technology and RL}

Students in higher education are "digital natives" (Prensky, 2001) who live within the context of digital technology in most aspects of their lives. Consequently, teachers and students must incorporate technology in their teaching and learning practices. Becoming technologically literate goes beyond learning technical skills; it requires broadening the capacity to think critically regarding the abundance of technology. Learning about design and technology enables learners to question, challenge, detect, deconstruct, and become empowered to affect change. In their development and use, technologies are influenced by and can play an important role in transforming, restoring, and sustaining our societies and our natural managed, constructed, and digital environments (Best, 2017).

Alkandari (2015) observed that the conventional methods for Islamic studies at the College of Education in Kuwait University rely significantly on lectures, discussions, and presentations, leading to an evident weakness in students' achievement. However, the Kuwait University College of Education programs encourage preservice students to design and incorporate technology within their future teaching practices. Exposing preservice teachers to designing the RL classroom allows them to develop planning skills, solve design problems, and develop creativity in combining design with content.

This paper explores various intertwined concepts, such as whether preservice Islamic studies teachers designing an RL project enhanced their AL skills and efficacy in integrating design and technology in their subsequent teaching. It further explores how designing the RL project affected their opinion of incorporating technology within Islamic studies and if this influenced their centric learning AL endeavor.

\section{Research questions}

From the above, the following research questions were developed:

RQ1: What elements of designing an RL project influenced preservice Islamic studies teachers and affected their AL?

RQ2: What learning experience did preservice Islamic studies teachers attain from integrating technology within Islamic studies content to create an RL project?

\section{METHOD}

\section{Participants}

The participants included a purposeful sample of 31 preservice Islamic studies teachers at the College of Education, Kuwait University, who enrolled in the Basic Methods of Teaching Islamic Studies (BMTIS) course. 


\section{Data Collection}

The study was conducted over two semesters at the BMTIS through various phases of the RL project. First, the participants responded to an open-ended survey to explore their previous experiences with design, technology, and RL concepts. Second, RL as a teaching strategy was introduced theoretically, including using design and technology in preparing online videos and guidelines for integrating RL within subsequent teaching practices. Third, the participants attended a workshop run by an assistant professor specializing in educational technology on integrating technology in Islamic studies and innovative approaches for future teaching methods. The participants explored several software applications for designing videos for RL classrooms and the standards and criteria for creating suitable videos for the RL project. Online video samples customized for RL classrooms in Islamic studies were displayed to help the participants understand the project. Finally, the sample videos and activities were discussed, evaluated, and reflected upon to build a functional prototype for the RL project.

The project ran for three weeks, during which the participants planned, designed, and executed their videos and activities over multiple phases. The participants were asked to reflect on the process and their perception of the developed experiences and skills for integrating design within Islamic teaching and the RL project. They responded to a learning experience questionnaire (LEQ), adapted and administered to Islamic studies students' teachers at Kuwait University. The researchers obtained permission from the KTH Royal Institute of Technology to apply their valid questioner in Kuwait. The researchers took notes throughout the process, including during class discussions with the researchers and students. The final project phase involved the educational technology professor and primary class instructor evaluating the RL projects.

\section{Data Analysis}

The study applied both quantitative and qualitative approaches to answer the research questions. The LEQ data were analyzed quantitatively using SPSS version 25.0. The LEQ items were filled, verified, checked, matched manually, and arranged according to the division of the averages of the items' responses into five equal categories, with averages from 4.20 and above representing "strongly agree"; $3.40-4.19$ was "agree"; 2.60-3.39 was "neutral"; $1.80-2.59$ was "disagree"; and 1.79 or less was "strongly disagree."

In the second approach, reflection papers and collecting notes were used to collect quantitative data, which was then triangulated. The data sources were validated in phases, from collecting to coding and sorting, to capture significant insight and information and reach reliability to prevent researchers' biases (Jonsen \& Jehn, 2009). The authors analyzed the various data resources to elicit the participants' perceptions by comparing and categorizing them based on the main themes of the skills fostered in designing the RL project. The data were categorized into themes (Cohen et al., 2007; Lodico et al., 2010) and systematically, iteratively, and inductively explored. Notes and reflections were captured and labeled until all the code fragments were interrelated. Finally, the data were grouped thematically and analyzed. The interpretations' 
trustworthiness evolved through various phases among the authors through constant discussions to reach reliable coding and develop reflectiveness.

\section{FINDINGS AND DISCUSSION}

The data analysis produced various dimensions related to the participants' experiences with technology and design and its incorporation in Islamic studies. Additionally, the results illustrated the skills gained by emphasizing AL in the RL project.

\section{Design and Technology in Islamic Studies}

Incorporating design and technology in Islamic studies was perceived as utilizing devices and applications to facilitate teaching and learning. This allows efficient use of class time and elevates learning quality. Various recommendations and obstacles were revealed. Incorporating updated technology within Islamic studies teaching is an innovative approach. Alsharidah (2018) argued that Islamic studies needs to encourage the integration of technology. Göl (2012) noted that utilizing technology had farreaching effects on Islamic studies instruction. The participants expressed enthusiasm about integrating technology in their future teaching, noting that it would help present content in an innovative, progressive way. Students are now tech-savvy, and prospective teachers must keep up with these educational trends and innovations to promote positive learning tendencies and encourage students to become constructivist learners. One participant was hesitant to incorporate technology, stating, "I do not believe that using technology within my teaching practices suits the nature of Islamic studies. We can rely on lectures and discussion." Some students may hold negative beliefs that reflect on their future teaching practices: If higher education courses can positively shape preservice teachers' perceptions regarding a learning area, they are more likely to integrate such learning experiences in their subsequent classroom setting (Best, 2017). Skeptical preservice teachers should be encouraged to incorporate technology in their teaching through exposure early in their academic year, as beliefs viewed as rational consolidate actions.

\section{Skills Participants Acquired from The RL Project}

\section{AL skills}

The most significant skill the participants developed was working autonomously. One participant stated, "At the beginning, I felt frustrated, though ultimately it was such a transformational learning experience. It was a challenging endeavor, daunting, timeconsuming, but inspiring." Creating a learning environment that would enhance AL is layered with complexity, as it is highly immersed in students' intrinsic motivations and willingness, which rely strongly on students' resilience and self-determination. Cole et al. (2004) define student motivations to learn as "the willingness to attend and learn the material in the development program" (p. 67). Subsequently, teachers are responsible for enhancing students' self-determination to attain their learning outcomes, promote their self-competence, self-efficacy, recognize their individuality as learners, and applaud their achievements in taking the lead in their learning (Abeysekera \& Dawson, 2014; Mahasneh \& Alwan, 2018). 


\section{Design, creativity, and innovation}

The participants discussed their perceptions of design skills they developed through the RL project and how it revealed specific qualities: "I was skeptical about my designing skills regarding the video and activities. I searched for innovative programs and implemented it for the RL." Incorporating technology is not merely using technology but includes related thinking and planning skills to encourage teachers to include technology in their instruction. Teachers should rationalize suitable technological usage, the possible obstacles to achieving their lesson objectives, and how to receive the maximum benefit of its use (Beschorner \& Kruse, 2016). The participants demonstrated high tendencies toward integrating technology within their teaching practices, which required design skills. Constant training and early exposure help teachers become more creative and innovative in their future teaching practices. Goktas et al. (2009) noted that the lack of technological training among preservice teachers could cause software to become a significant barrier to integrating technology. Creativity is crucial in designing an RL project. The participants had to create ideas, promote imagination, solve problems, and conquer challenges. They successfully produced an authentic project, shaping the students' skills: "Designing the video for the RL project was time-consuming and daunting. I had to analyze the content to be transferred into the technological design. After several intensive attempts, I executed the video, which was a genuine learning experience for me." Preservice teachers may initially resist technology design, but it allows them to learn outside the box. Best (2017) described this as "turning ideas into outcomes" (p. 56) to help teachers think innovatively.

\section{Knowledge acquisition}

A significant aspect of promoting AL is that learners become self-directed toward creating a conceptual understanding and recognizing their skills. They can transform their comprehension of the learning process during their course through various channels, such as discussions, feedback, workshops, reflections, and observations. In this study, constructing a profound experience created enhanced, holistic cognition related to designing RL classrooms. One participant stated, "Despite being confronted by difficulties throughout executing the RL, I learned more about various applications to be integrated with my future practices; despite all the material, and workshops offered to design the RL class, I still had to read more information to perfect my project."

\section{Self-confidence}

Situating preservice teachers in an AL sphere also enhanced self-confidence. One participant said, "Honestly, I thought of dropping the course when RL was assigned, but after several attempts tinged with frustration and fear of failure, I managed to design the RL project. I know it might not be perfect, but I felt I can improve my skills in technology and design." Tondeur et al. (2012) observed that preservice teachers are usually skeptical and less confident regarding their competence in integrating technology into their practices. Throughout the academic enterprise, prospective teachers need to be empowered academically and, more significantly, psychologically, highlighting how individuals construct self-efficacy and competence (Zavattaro et al., 
2018). However, in the participants' reflections and open discussions, they stated that they gained self-efficacy to experiment. The design and technology to be integrated into their subsequent practice empowered the participants and raised their self-confidence.

Reflective thinking and problem-solving

Another skill that emerged from fostering AL with the RL design project is reflective thinking, which allows preservice teachers to think about their learning process and select the best solutions to manage challenges (Gencel \& Saracaloğlu, 2018). Students' reflective thinking occurs with the process of recurring, comprehending, and internalizing the knowledge to construct and deduce a novel perspective. By fulfilling the RL project requirements, the participants became more self-directed and reflective learners. Several intellectual layers were unveiled, such as conceptual understanding for the situation they had been through, problem-solving for emerging obstacles to achieve their project objectives, and becoming proficient in the skills required for finalizing the requirements: "Through constant attempts and feedback, I manage to overcome several obstacles. Execution the RL project allowed me to explore skills I thought I never had, such as design and technology, and integrating it with Islamic studies."

\section{Practice and learning effectiveness}

Another skill promoted was self-centered learning tendencies directed toward transforming how the educational process was viewed as "initial personal training" (Siminică \& Traistaru, 2013, p. 5). Constant training in AL allows students to obtain knowledge and become actively engaged in the learning process, represented in reading, planning, brainstorming, designing, reflective thinking, collaborating, and communicating. Practicing and experimenting with these skills resulted in productive learning, demonstrating that situating student practices by enforcing AL fosters selfregulated tendencies (Gilbert \& Driscoll, 2002; Jossberger et al., 2010; Lee \& Teo, 2010):

When I started executing the video for the RL project, I went through several attempts. Each mistake I made was a step forward to finalizing the project. I learned the hard way, but it was worth it; the several unsuccessful attempts were fruitful.... Now I feel confident and competent to create better videos for my future students.

Additional skills were addressed through the LEQ to reveal insights into the student experiences during the RL and to integrate the technology. The LEQ was organized into four main levels: Meaningful-emotional, Comprehensibility-cognitive, Manageabilityinstrumental, and the learning factors experienced through the RL project. Table 1 illustrates the overall experience in the four main levels obtained by the participants. Tables 2, 3, 4, and 5 illustrate the results of the items at each level. 
Table 1

Mean and standard deviations for the total factors

\begin{tabular}{llll}
\hline Levels & Mean & $\begin{array}{l}\text { Standard } \\
\text { deviation }\end{array}$ & $\begin{array}{l}\text { Items sorted by } \\
\text { means }\end{array}$ \\
\hline Meaningfulness-emotional level & 3.97 & 0.462 & 4 \\
\hline Comprehensibility-cognitive level & 4.33 & 0.390 & 1 \\
\hline Manageability-instrumental level & 4.08 & 0.451 & 3 \\
\hline Learning factors experienced from the RL project & 4.24 & 0.376 & 2 \\
\hline Total & 4.21 & 0.336 & \\
\hline
\end{tabular}

The data presented in Table 1 illustrate the overall experience from the four main levels, and the overall mean was $4.21, \mathrm{SD}=0.336$.

Table 2

Mean and standard deviations for the responses to each statement (Meaningfulness emotional level)

\begin{tabular}{llll}
\hline Meaningfulness-emotional level items & Mean & $\begin{array}{l}\text { Standard } \\
\text { deviation }\end{array}$ & $\begin{array}{l}\text { Items sorted by } \\
\text { means }\end{array}$ \\
\hline I worked with interesting issues & 4.39 & 0.667 & 1 \\
\hline I explored parts of the task on my own & 3.90 & 1.012 & 4 \\
\hline I was able to learn by trying out my own ideas & 3.94 & 0.892 & 3 \\
\hline The project was challenging in a stimulating way & 3.42 & 1.119 & 6 \\
\hline I felt togetherness with others on the project & 3.77 & 1.203 & 5 \\
\hline The atmosphere in the course was open and inclusive & 4.39 & 0.761 & 2 \\
\hline
\end{tabular}

The statement "I worked with interesting issues" came first in the Meaningfulnessemotional level (Mean=4.39, $\mathrm{SD}=0.761$ ), while the statement "The project was challenging in a stimulating way" came last (Mean=3.42, $\mathrm{SD}=1.119)$.

Table 3

Mean and standard deviations for the responses (Comprehensibility-cognitive level)

\begin{tabular}{llll}
\hline Comprehensibility-cognitive level items & Mean & $\begin{array}{l}\text { Standard } \\
\text { deviation }\end{array}$ & $\begin{array}{l}\text { Items sorted } \\
\text { by means }\end{array}$ \\
\hline $\begin{array}{l}\text { The intended learning outcomes helped me understand what I was } \\
\text { expected to achieve }\end{array}$ & 4.42 & 0.564 & 3 \\
\hline $\begin{array}{l}\text { I understood how the project was organized and what I was } \\
\text { expected to do }\end{array}$ & 4.32 & 0.702 & 7 \\
\hline I understood what the teachers were talking about & 4.23 & 0.990 & 8 \\
\hline I was able to learn from concrete examples that I could relate to & 4.16 & 0.735 & 9 \\
\hline Understanding key concepts had a high priority & 4.55 & 0.568 & 1 \\
\hline $\begin{array}{l}\text { Activities helped me achieve the intended learning outcomes } \\
\text { efficiently }\end{array}$ & 4.55 & 0.624 & 2 \\
\hline I understood what I was expected to learn to obtain a certain grade & 4.39 & 0.761 & 4 \\
\hline I received regular feedback that helped me see my progress & 4.39 & 0.667 & 5 \\
\hline I could practice and receive feedback without being graded & 3.94 & 0.892 & 10 \\
\hline The assessment of the project was fair and honest & 4.39 & 0.761 & 6 \\
\hline
\end{tabular}

The statement "Activities helped me achieve the intended learning outcomes efficiently" came first (Mean $=4.55, \mathrm{SD}=0.624$ ), while the statement "I could practice and receive feedback that helped me see my progress" came last (Mean $=3.94, \mathrm{SD}=0.892)$. 
Table 4

Mean and standard deviations for the responses (Manageability-instrumental level)

\begin{tabular}{llll}
\hline Manageability-instrumental level items & Mean & $\begin{array}{l}\text { Standard } \\
\text { deviation }\end{array}$ & $\begin{array}{l}\text { Items sorted } \\
\text { by mean }\end{array}$ \\
\hline My background knowledge was sufficient to follow the project & 3.35 & 1.170 & 6 \\
\hline I regularly spent time reflecting on what I learned & 3.71 & 0.864 & 5 \\
\hline I was able to learn in a way that suited me & 3.97 & 0.752 & 4 \\
\hline I had opportunities to choose what to do & 4.35 & 0.709 & 3 \\
\hline I was able to learn by collaborating and discussing with others & 4.65 & 0.486 & 1 \\
\hline I was able to get support if I needed it & 4.45 & 0.723 & 2 \\
\hline
\end{tabular}

The statement "I was able to learn by collaborating and discussing with others" came first (Mean $=4.65, \mathrm{SD}=0.486$ ), while the statement "My background knowledge was sufficient to follow the project" came last (Mean $=3.35, \mathrm{SD}=1.170)$.

Table 5

Means and standard deviations for the responses (learning factors)

\begin{tabular}{|c|c|c|c|}
\hline Learning factors experienced through the RL project items & Mean & $\begin{array}{l}\text { Standard } \\
\text { deviation }\end{array}$ & $\begin{array}{l}\text { Items sorted } \\
\text { by means }\end{array}$ \\
\hline $\begin{array}{l}\text { We are trying to answer questions, solve problems, or acquire skills that we } \\
\text { find interesting, intriguing, or important }\end{array}$ & 4.39 & 0.558 & 4 \\
\hline $\begin{array}{l}\text { We can speculate, try out ideas (intellectually or practically), and learn from } \\
\text { experience even before we know much about the project }\end{array}$ & 4.00 & 0.816 & 13 \\
\hline We can do so in a challenging yet supportive environment & 4.23 & 0.956 & 8 \\
\hline $\begin{array}{l}\text { We feel that we are part of a community and believe that other people have } \\
\text { faith in our ability to learn }\end{array}$ & 4.61 & 0.558 & 2 \\
\hline $\begin{array}{l}\text { We understand the meaning of the intended learning outcomes, how the } \\
\text { environment is organized, and what is expected of us }\end{array}$ & 4.26 & 0.631 & 7 \\
\hline $\begin{array}{l}\text { We have sufficient background knowledge to manage the present learning } \\
\text { situation }\end{array}$ & 4.13 & 0.806 & 9 \\
\hline $\begin{array}{l}\text { We can learn inductively by moving from specific examples and } \\
\text { experiences to general principles, rather than the other way around }\end{array}$ & 4.13 & 0.763 & 10 \\
\hline $\begin{array}{l}\text { We are challenged to develop a proper understanding of key concepts and } \\
\text { successively create a coherent whole of the content }\end{array}$ & 3.68 & 1.045 & 14 \\
\hline $\begin{array}{l}\text { We believe that the work we are expected to do will help us to reach the } \\
\text { intended learning outcomes }\end{array}$ & 4.45 & 0.568 & 3 \\
\hline $\begin{array}{l}\text { We can try, fail, and receive feedback in advance of and separate from any } \\
\text { summative judgment of our efforts }\end{array}$ & 4.32 & 0.748 & 5 \\
\hline We believe that our work will be considered fairly and honestly & 4.71 & 0.588 & 1 \\
\hline We have sufficient time to learn and devote the time necessary to do so & 4.10 & 1.012 & 11 \\
\hline $\begin{array}{l}\text { We believe that we are in control of our own learning and not being } \\
\text { manipulated. }\end{array}$ & 4.06 & 0.814 & 12 \\
\hline $\begin{array}{l}\text { We can work collaboratively with other learners struggling with the same } \\
\text { problems }\end{array}$ & 4.29 & 0.902 & 6 \\
\hline
\end{tabular}

The statement "We believe that our work will be considered fairly and honestly" came first (Mean= 4.71, SD =0588), while the lowest statement was "We are challenged to develop a proper understanding of key concepts and successively create a coherent whole of the content" $($ Mean $=3.68, \mathrm{SD}=1.045)$. 


\section{DISCUSSION OF THE LEARNING EXPERIENCE QUESTIONNAIRE (LEQ)}

One of the main findings of the LEQ was that the participants demonstrated enthusiasm in working autonomously to design and execute the RL project leading to achieving substantial independence and generating willingness and motivation (Best, 2017). The level of motivation and self-determination to learn and work with the material relates to the degree of autonomy. Designing the RL project was embedded with emphasizing AL. The participants also indicated that the course's atmosphere was open and inclusive. Students work and learn effectively when teachers are more concerned about the learning process than merely the learning outcomes, creating a learning environment that increases their sense of autonomy, competence, and applicability (Abeysekera \& Dawson, 2014). Further, working autonomously is an innovative practice for participants and might be challenging. However, undergoing this challenge was not confronted individually; instead, the project broadly promoted communication and collaboration in group discussions, analyses, problem-solving, asking questions, providing constructivist critiques to other projects, and constructive feedback. These practices will eventually generate an authentic learning leap among students (Best, 2017).

The participants demonstrated a higher level of comprehensibility at the cognitive level; they stated that undergoing this active learning environment led to authentic, meaningful learning experiences. Understanding occurs within engagement and active learning (Inan et al., 2019). Participants' self-learning experiences designing the RL project supported their conceptual understanding of the theoretical level and relating it through planning and designing. Through this project, preservice teachers combined their knowledge with activities and aligned them with substantial learning (Steen-Utheim \& Foldnes, 2018).

The participants demonstrated an appreciation for working collaboratively in designing the RL project, as it fostered skills in executing projects. Collaborative work among the participants allowed the students to create and articulate knowledge and reflect on the learnings from the project design. Collaborations help learners obtain both explicit and invisible knowledge. Project-based learning in RL encouraged AL and highlighted the importance of cooperation and communication between students and teachers, whether personally or through a technological medium (Zavattaro et al., 2018).

Finally, the participants demonstrated trustworthiness and a sense of appreciation in working autonomously in the RL project. Students' individualism needs to be recognized by their classmates and their teacher (Steen-Utheim \& Foldnes, 2018). Exposing them to a novel practice encouraged worthiness and self-appreciation. It is the teacher's main responsibility to enable students to achieve their potential and unveil their skills and abilities. Throughout this project, the participants gained skills and values related to their AL endeavors, such as planning, active engagement, self-learning, responsibility, reaching goals, management, confronting challenges, working innovatively, and collaborating, fulfilling their self-worth as individual learners. 


\section{CONCLUSIONS}

This paper demonstrated that the RL project shaped the participants' beliefs toward selfregulation, responsibility, technology integration, and design for subsequent Islamic studies teaching positively and profoundly. Additionally, the participants' AL growth was promoted through the RL project by introducing them to a novel practice that empowered the participants' self-learning, autonomy, active learning, self-regulation, and responsibilities. The participants concluded that Islamic education is not traditionalist and can employ innovative educational trends within its teaching practices. As this research focuses on only preservice Islamic studies teachers, future research must explore their subsequent implementation of practices to design RL in schools. It is also necessary to introduce preservice teachers in other specializations to projects that emphasize self-learning and enforce autonomy within the learning environment.

\section{REFERENCES}

Abeysekera, L., \& Dawson, P. (2014). Motivation and cognitive load in the flipped classroom: Definition, rationale, and a call for research. Higher Education Research and Development, 34(1), 1-14.

Al Juhami, A. (2008). Significant teaching competencies for elementary Islamic studies teachers: Supervisor's perspectives. Majalat Al Tarbiya. Al Azhar University, 35, 5399.

Alkandari, B. (2015). An investigation of the factors affecting students' acceptance and intention to use e-learning systems at Kuwait University: Developing a technology acceptance model in e-learning environments. [Unpublished doctoral dissertation]. Cardiff Metropolitan University.

Alkandari, K., \& Alsuwailan, Z. (2019). Pressures confronting Islamic studies curricula in Kuwait: Perspectives of curricula planners on challenges and confrontations. Religious Education, 114(2), 1-13.

Alsadoon, A. (2012). Methods in teaching in Islam and methods of its evaluation. Majalt Al Oustth, 203, 1113-1136.

Alsharidah, M. (2018). Creating change in the use of information and communications technology by female Islamic studies teachers in Saudi Arabia. International Journal of Educational Administration and Policy Studies, 10(3), 17-24.

Alvarez, B. (2012). Flipping the classroom: Homework in class, lessons at home. Education Digest: Essential Readings Condensed for Quick Review, 77(8), 18-21.

Bergmann, J., \& Sams, A. (2012). Flip your classroom: Reach every student in every class every day. Washington DC: International Society for Technology in Education.

Beschorner, B., \& Kruse, J. (2016). Preservice teachers' use of a technology integration planning cycle: A case study. International Journal of Education in Mathematics, Science, and Technology, 4(4), 258-271. 
Best, M. (2017). Transforming preservice teachers' beliefs and understandings about design and technologies. Australian Journal of Teacher Education, 42(7), 47-65.

Cohen, L., Manion, L., \& Morrison, K. (2007). Research methods in education (6th ed.). Routledge.

Cole, M., Feild, H., \& Harris, S. (2004) Student learning motivation and psychological hardiness: Interactive effects on students' reactions to a management class. Academy of Management Learning and Education, 3(1), 64-85.

Duke, N. K. (2016). Project-based instruction: A great match for information texts. American Educator, 40(3), 4-11.

Endut, M., \& Abdullah, W. (2009). Towards the conceptual definition of critical Islamic thinking. Retrieved 5 February 2020 from https://eprints.utp.edu.my

Gencel, I., \& Saracaloğlu, A. (2018). The effect of layered curriculum on reflective thinking and on self-directed learning readiness of prospective teachers. International Journal of Progressive Education, 14(1), 8-20.

Gilbert, N., \& Driscoll, M. (2002). Collaborative knowledge building: A case study. Educational Technology Research and Development, 50, 59-79.

Goktas, Y., Yildirim, S., \& Yildirim Z. (2009). Main barriers and possible enablers of ICT's integration into preservice teacher education programs. Educational Technology and Society, 12(1), 193-204.

Göl, A. (2012). Constructing knowledge: An effective use of educational technology for teaching Islamic studies in the UK. Education and Information Technologies, 17(4), 399-416.

Inan, N. K., Balakrishnan, K., \& Refeque, M. (2019). Flipping perceptions, engagements and realities: A case study. Turkish Online Journal of Distance Education, 20(1), 208-222.

Jonsen, K., \& Jehn, K. (2009). Using triangulation to validate themes in qualitative studies. Qualitative Research in Organizations and Management: An International Journal, 4(2), 123-150.

Jossberger, H., Brand-Gruwel, S., Boshuizen, H., \& Wiel, M. (2010). The challenge of self-directed and self-regulated learning in vocational education: A theoretical analysis and synthesis of requirements. Journal of Vocational Education and Training, 62(4), 415-440.

Kozikoğlu, İ. (2019). Analysis of the studies concerning flipped learning model: A comparative meta-synthesis study. International Journal of Instruction, 12(1), 851-868.

Kuwait Ministry of Education. (2013). A framework of reference and implementation of the program of the Ministry of Education. Retrieved 22 September 2019 from www.moe.edu.kw/docs/Wathaiq/ReferenceFram/ReferenceFram.pdf 
Lee, C. B., \& Teo, T. (2010). Fostering self-directed learning with ICT. In C. S. Chai \& Q. Wang (Eds.), ICT for self-directed and collaborative learning (pp. 39-51). Pearson.

Li, X., Randy, L., \& Lijun, M. (2018) Track effect: Unraveling the enhancement of college students' autonomous learning by using a flipped classroom approach. Innovations in Education and Teaching International, 55(5), 521-532.

Lodico, M., Spaulding, D., \& Voegtle, K. (2010). Methods in educational research: From theory to practice (2nd ed.). Jossey-Bass.

Mahasneh, A. M., \& Alwan, A. F. (2018). The effect of project-based learning on student teacher self-efficacy and achievement. International Journal of Instruction, 11(3), 511-524.

Nguyen, B., Yu, X., Japutra, A., \& Chen, C. H. S. (2016). Reverse teaching: Exploring student perceptions of "flip teaching." Active Learning in Higher Education, 17(1), 5161.

Prensky, M. (2001). Digital natives, digital immigrants, part 1. On the Horizon, 9(5), 16.

Siminică, M., \& Traistaru, A. (2013). Self-directed learning in economic education. International Journal of Education and Research, 1(12), 1-14.

Steen-Utheim, A. T., \& Foldnes, N. (2018). A qualitative investigation of student engagement in a flipped classroom. Teaching in Higher Education, 2(3), 307-324.

Tondeur, J., van Braak, J., Sang, G., Voogt, J., Fisser, P., \& Ottenbreit-Leftwich, A. (2012). Preparing preservice teachers to integrate technology in education: A synthesis of qualitative evidence. Computers and Education, 59, 134-144.

Zavattaro, S. M., Kus, K., Lademann, J., \& Peeple-Briggs, E. A. (2018). View from the inside: Collaborating with students to flip the classroom in real time. College Teaching, 66(2), 88-97.

Zedan, A., Yusoff, M. Y., \& Mohamed, R. (2015). An innovative teaching method in Islamic studies: The use of PowerPoint in the University of Malaya as a case study. Procedia - Social and Behavioral Sciences, 182, 543-549, https://doi.org/10.1016/j.sbspro.2015.04.776 